\title{
MI ENTIERRO DE CLARÍN: UN CUENTO RARO
}

\author{
Pedro Pablo VIÑUALES \\ Universidad Complutense
}

No pretendo con el presente artículo señalar, como hiciera Gramberg respecto de los paliques, un olvido ni un menosprecio por parte de la crítica hacia este relato. No cabe duda de que Mi entierro, firmado en Zaragoza en 1882 y publicado en La Ilustración Artística el 26 de marzo de 1893, es una nota disonante y atractiva dentro de la sinfonía realista que suponemos al hablar de la obra de Leopoldo Alas. No obstante, si lo asociáramos a otros dos cuentos como son Avecilla y Amor' è furbo de ese mismo año, reuniríamos una trilogía peculiar en la que "parece dominar el acento frívolo" (Ramos-Gascón, 1984, pág. 77)'. Se ha comentado, por supuesto, el contraste que supone esta zona de su creación. Porque si el 16 de marzo de 1882 Clarín apuntaba en La Diana que el arte debía dejar de ser vago soñar, tres meses después escribe en el mismo diario cómo en el arte intervienen "el sentimiento y otros modos de conocimiento que el mero pensar racional” (cit. Lissorgues, 1989a, I, pág. 46).

Disponemos además de antecedentes como El doctor Pértinax o como La mosca sabia, escritos poco antes, y en los que, tanto el estilo como el tema, se alejan bastante de ese positivismo literario preconizado por el Naturalismo. Así, rastreando este género de relatos, nos remontamos al primerizo Juan Ruiz, donde el joven Leopoldo confesaba el proyecto de dar salida a una serie de narraciones extraídas de un librito original titulado Cuentos raros que pronto estará a la venta. Siendo encabezada por El Caramelo la idea no tuvo continuación, e, independientemente de que estuviera concluida o no, cabe considerarla como síntoma de un impulso inquieto y renovador (vid. Alas, 1985, pág. 100).

1. Estas palabras se refieren, concretamente, a Amor' è furbo; yo las hago extensibles a cualquiera de los tres relatos. En lo referente a Mi entierro, todas las citas llevarán la paginación correspondiente a esta edición de Cátedra que prologa Ramos-Gascón. 
Con la intención de asumir que Mi entierro es, al cabo, hijo de su tiempo, lo cual no es óbice para resaltar su modernidad, se le ha relacionado con los cuentos de Galdós, cargados de imaginería romántica, con las Narraciones Inverosímiles de Alarcón ${ }^{2}$, y hasta con Poe. Me ha llamado la atención, por otra parte, que se mencione cada vez más este relato, desde Gramberg (1958) hasta las últimas antologías, la de Richmond (1983) o de Lissorgues (1989b). Sin embargo, tal vez su calidad de experimento narrativo, ha desconcertado a todos los que han intentado clasificarlo.

"También en algún caso de la parte narrativa de su obra vence la fuerza narrativa a la preocupación por un contenido moral", comenta E. Gramberg, para concluir: "El resultado es, entonces, la farsa, de la cual hay bastante en Cuento futuro, Mi entierro y en ciertos episodios de Apolo en Pafos (1958, pág. 189). Laura de los Ríos, por su parte, lo incluye en la categoría de los grotescos, y lo relaciona con el expresionismo alemán. Del diálogo con el sereno, concretamente, opina que se trata de "una de las páginas cómicas más originales de Alas (...), de una modernidad muy cercana a nuestros días y al humor de un Gómez de la Serna o de algunos cuentos de Isak Dinesen" (1965, pág. 288); y señala cómo el final resulta "realmente desconcertante, no exento de un vago simbolismo, enlaza los planos de vida, sueño y muerte" (ibid., pág. 290).

Otra clasificación establecen para este cuento Ramos-Gascón e Y. Lissorgues. E1 primero destaca "de esta fantástica historia [...] su calidad de inverosímil" (1984, pág. 79). Las fuentes a las que acude seguidamente, sin llegar hasta las Danzas de la Muerte o a Los sueños de Quevedo, hacen bascular el tratamiento del tema ya hacia lo extraño, ya hacia lo maravilloso, empleando la terminología de Todorov (1970). Por otro lado, el Muérete y verás de Bretón de los Herreros, a que alude, se relaciona con la tradición, como señala G. Sobejano, y es asociable a otros ejemplos de paremiología popular. El dicho puesto en boca del sereno por el autor: "Muerto el perro..." (pág. 168), en su contexto bien pudiera ser complementado con aquel otro: "El muerto al hoyo..." Con todo, este tipo de fuentes poco explican la forma en que Clarín trabajó este relato, sirviendo sólo de referencias muy fragmentarias. Regresando al hilo de mi exposición puedo resumir que tanto Ramos-Gascón como Y. Lissorgues consideran éste un relato fantástico, mientras que G. Sobejano se refiere a él como maravilloso (1985, pág. 84).

Más ecléctica, C. Richmond afirma que se trata de "uno de los cuentos más imaginativos de Clarín. Con una ironía juguetona, se le ofrece al lector - cuya participación es, en este caso, esencial - una riqueza de posibilidades

2. Sabemos que escuchaba complacido sus rarísimos sucesos durante la infancia, según declara en El niño de la bola, de Solos de Clarín (1971, pág. 213). 
interpretativas, y encuentra sus raíces, no tanto en la fantasía de la sinrazón como en aquella locura de la razón que es la borrachera" (1983, pág. 337). Pienso que con esto se está refiriendo al mecanismo de lo imaginario en el proceso creativo, no a la realidad del narrador, el cual — como advirtió la propia Richmond- ofrece una lectura plurívoca.

Por último, R. Eberenz, resaltando lo singular de cada obrita como experiencia individual, describe este cuento como "una imbricación de lo real con lo fantástico y del humor negro” (1989, pág. 29), atribuyendo las vivencias progresivamente fantásticas a la demencia del personaje-narrador, y concluye tildándolo de fantasia macabra (ibíd, pág. 111 y 168).

Trataré de revisar en breve las diversas lecturas ofrecidas por el cuento, revisando las voces que configuran el discurso del narrador.

Desde el principio nos instalamos en un discurso autodiegético, con todo lo que ello implica de necesaria complicidad con el lector. Pero muy pronto el plano de lo cognoscible se aleja y debemos dejarnos conducir por la subjetividad que gobierna "aquella humedad en los pies podía volverme loco, por ejemplo" (pág. 617); la relación causa-efecto se nos ha hecho extraña. De aquí, no obstante, dimanará la lógica de las progresivas alucinaciones, en coherencia con la previamente manifiesta afición ajedrecística. La identificación real de los personajes, (policías, sereno, criado...) se superpone a las imágenes de esta obsesión dando lugar a una doble visión.

Tras la primera clave ofrecida por el narrador, la de su propia locura, un personaje plantea otra: "dicen si ha muerto de una borrachera" (pág. 168), y poco después Perico apunta una tercera: "de un ataque cerebral". De seguido, el fenómeno fantástico del desdoblamiento, introducido ya con el error de identificar al personaje-narrador con el que viene a amortajar, es tratado de modo antifantástico, es decir, con la plena aquiescencia del afectado. Ello aumenta el estupor de quien lee, su distanciamiento. Y el episodio que sigue acentúa esta lógica onírica retomando, como un leit motiv, la humedad en los pies.

Predispuestos por esta perspectiva inverosímil, el narrador pasa a ofrecernos las descripciones de los personajes que siguen, la mujer y el amante, los del partido, ya sin distorsión irracional alguna; incluso focaliza el discurso, como si de una narración realista se tratara, en la figura de D. Mateo Gómez, reproduciendo fielmente, en estilo directo, varias conversaciones en torno, y siendo capaz incluso de corregir a este personaje como narrador delegado: "D. Mateo dudaba si caracteres era esdrújulo" (pág. 174), o "nunca había sabido don Mateo si se dice así alas o aras" (pág. 175), mostrando una omnisciencia completa.

Cuando ya parece que la normalidad es estable, nuevamente interrumpe el narrador: "... mártir de la idea (de la humedad, señor mío, de la humedad", 
(págs. 175-6). En este punto del relato, de tensión apenas manifiesta, un nuevo cambio nos sorprende: “iMientes! — grité saltando de la caja. Pero no había nadie" (pág. 176), conduciéndonos de improviso a la extrañeza primera con un final que, ya sin resolución, recoge la repetida idea de la humedad y las imágenes ajedrecísticas. El cuento queda de este modo cerrado, sin posible interpretación más allá de él mismo, y el lector, que al entrar a una historia contada en pasado, podía haber intuido que se estaba recuperando una anécdota pasajera, queda absolutamente desconcertado. Por eso su asentimiento es aquí fundamental, como si se tratara de la lectura de un poema. Al coincidir la visión que actúa con la que narra, no extraemos una verificación epistemológica que pueda sustraernos del subjetivismo motriz. Pero esto, que de ordinario no supone más que la cesión de crédito, se trueca, en estas circunstancias, con la irrupción del absurdo, en una condición sine qua non. La asociación ridícula de volverse loco a causa de tener los pies mojados es, no obstante, verosímil en el plano de los personajes; así, Perico comenta las palabras de Clemente Cerrojos a la adúltera: "Tu marido se quita de enmedio el mejor día reventando de bestia y por mojarse los pies después de calentarse los cuernos" (pág. 618). Además habíamos leído, como anticipé:... volverme loco, por ejemplo, lo cual acentúa el carácter familiar que el fenómeno, como algo ya conocido, parece tener para el protagonista, cuyo campo de lo verosímil es diferentes al nuestro. Esa relatividad, ya que no asombro, al personaje le produce cierto fastidio, expresado de continuo con un Por de pronto... De este modo parece que el sujeto es testigo paciente de su propio cambio en el ámbito de lo gnoseológico. La confusión aumenta, porque vemos que el narrador juega con los planos real e imaginario, contrastándolos y poniendo sobre aviso de la progresiva distorsión, y siendo capaz de interpretar la psicología de los otros personajes y no la propia. Así, por ejemplo, reconoce por la voz que Perico, su criado, acababa de despertarse, pero no se cuestiona, ni aclara al lector, sobre su estado propio.

Desde que confunde a los policías con las torres negras, cualquier elemento actante puede ser enfocado bajo esta obsesión de ajedrecista. La dualidad que con ésta se abre nos puede hacer deducir que se trata, en todo caso, de una locura temporal, la cual es corregida desde un presente narrativo; es decir, que el narrador racionaliza la visión alucinada del personaje -él mismo en el pasado.

Acudiendo ahora a las digresiones de otro personaje-narrador, el de El Horla de Maupassant, acerca de su locura, leemos: "He conocido algunos que seguían siendo inteligentes, lúcidos y sagaces en todas las cosas de la vida menos en un punto. Hablaban de todo con claridad, facilidad y profundida, pero de pronto su pensamiento chocaba contra el escollo de la locura y se hacía pedazos..." (1976, pág. 151). Cabe decir que el tratamiento que Clarín hace del tema no tiene nada de trágico ni de angustiante para el personaje, quien no duda, como es habitual en los asiduos a lo fantástico, de su locura. 
Al finalizar el cuento en este mismo ambiguo estado mental, debemos replantear nuestro prejuicio, el cual consideraba una vuelta a la racionalidad. No hay más remedio que poner entre interrogantes la validez de la locura, pues sabemos que el psicótico "no sería capaz de distinguir esos diferentes marcos entre sí y confundiría lo percibido y lo imaginario" (Todorov, 1970, pág. 138). La explicación de por qué el autor ha insinuado esta interpretación es bastante conocida de todos: lo mismo que los excesos sexuales suelen ser relacionados con lo diabólico, los excesos de lo irracional se toleran mejor si son puestos en boca de un loco. Exactamente igual ocurre con las verdades que tocan lo tabú, son desveladas por mentes que de algún modo están desinhibidas, ya por su inocencia, ya por causas congénitas, ya por efecto del alcohol o alucinógenos. En Zurita, por citar otro cuento del asturiano, Aquiles desnuda su pensamiento en una borrachera.

Continuando con este aspecto, Todorov establece dos tipos de episodios en el relato elemental: "los que describen un estado de equilibrio o desequilibrio, y los que describen el paso del uno al otro. Los primeros se oponen a los segundos como lo estático a lo dinámico". Precisamente obervamos que este salto de lo verosímil a lo inverosímil en el plano del lector se produce sin reposo ni reflexión en el ámbito del narrador, desde que éste tropezó con la humedad.

Este mismo recurso narrativo, el que un hecho aparentemente inicuo descabale una situación o a un personaje, lo encontramos en el divertidísmo José Ido, de Fortunata y Jacinta, quien tras la ingestión de carne cree ciegamente que su mujer es adúltera y sólo entonces lo cree. Pero aún mayor paralelismo veo que existe entre éste y el cuento de Leopoldo Lugones La última carambola, en el que un personaje obsesionado por la precisión de su entretenimiento favorito, el billar, se vuelve loco al desequilibrar el peso de su bolsillo dando una limosna. Inmediatamente imagina que el Sol y la Tierra son dos enormes bolas de un billar de dimensiones cósmicas y que se va a producir un choque interplanetario. Sucede que estalla una bomba a su lado, con lo que su imaginación, de modo profético, se ha enlazado a este referente. En Mi entierro, narrado en primera persona, no contamos siquiera, como vimos, con un último desarrollo objetivo, de modo que su ambigüedad queda irresuelta. No cabe la posibilidad de interpretar la doble consecuencia narrativa como un sincretismo de dos tiempos. El cuento se desliza en ese estado intermedio entre el absurdo aparente de la locura y la ironía del escepticismo.

Indudablemente hay que hablar de la utilización por parte del escritor de un deslizamiento hacia el ensueño, hacia lo que Juan de Mairena llamaba desdeñosamente oniroscopia. La técnica no era habitual entonces, pero tampoco inconcebible. "Este método fue ya empleado en el siglo XVIII, época fértil 
en novedades extravagantes, donde fantasía y realidad se mezclan sin cesar. A este propósito Bretón cita una carta de Horace Walpole a William Cole que revela la génesis de una de sus obras, The castle of Otranto. Inspirado en un sueño redactó su obra en un estadio intermedio entre la vigilia y el sueño de un modo puramente espontáneo (cit. Duplessis, 1972, pág. 42). Narraciones de este tipo se encontraban, por supuesto, en Poe o Stevenson, pero también en la literatura peninsular, en Ros de Olano, o en Silverio Lanza poco después. Más adelante retomaré el tema.

Respecto a la contradicción entre los componentes léxicos señalada por Eberenz, pues "un difunto no habla" (1989, pág. 252), podemos ampliar dicha contradicción afirmando que tampoco un demente razona con dos lógicas, dos modos de ver el mundo, simultáneamente. Como dice Jacques Finné: "Si le lecteur sait, dès premières lignes, qu'il va lire une confession d'un dement, le récit acquiert une dimension réaliste qui exile le fantastique: la description du réel donnée par un malade sera naturellement malade" (1980, pág. 73) ${ }^{3}$. No es preciso ahondar más en la naturaleza del delirio como imagen que fuerza la realidad destruyendo el objeto, y basta ver cómo en Mi entierro presencia y simulación subjetiva se complementan intercambiando sus sentidos. En cambio "una secreta lógica gobierna las ensoñaciones que parecen abandonarse a los caprichos de la imaginación" (Vax, 1981, pàg. 96).

El propio Alas opinaba, hablando del estilo de Ortega Munilla, con respecto a "esa especie de enfermedad nerviosa de muchos poetas, que les hace ver junto al objeto y a veces en él mismo, las semejanzas que tiene en otros reinos de la realidad; ese prurito de la alegría no como recurso retórico, sino como efecto de la doble-vista estética del escritor [...] Es bueno ver todo lo que hay, pero es malo ver más de lo que hay" (vid. Bonet Mojica, 1984). La técnica, naturalmente más propia de la poesía, podía pasar a la prosa a través de numerosas vías, una de ellas lo fantástico (en el sentido amplio), otra por los juegos del humor, rupturas del sistema en diferentes sentidos.

Gramberg es quien atribuye a Clarín una imaginación febril (1958, pág. 204), contrapunto del escritor realista, que había dado a la novela un papel muy específico, pero que se permitía, según mostró, cierto respiro en el cuento. La profusa imaginación hasta agobiante en el estilo, que es derrochada por Galdós en sus relatos, resulta igualmente destacable. Si ahora leemos unas glosas que Menéndez Pelayo hace de Richter: "La facultad artística por excelencia es la imaginación; pero no la imaginación reproductora [...] sino la imaginación productora, o fantasía, que es el alma del mundo de nuestra alma" (cit. Bonet

3. "Si el lector sabe, desde las primeras líneas, que va a leer una confesión de un demente, el cuento adquiere una dimensión realista que aleja lo fantástico: la descripción de lo real hecha por un chiflado estará naturalmente tarada". 
Mojica, 1984, pág. 956n), y las comparamos con los artículos de La Diana mencionados, nos haremos una idea clara de lo poco claras que, en este punto, andaban las ideas. Se hace necesario citar aquí la frase de Renan que argumenta Clarín para defenderse de un ataque de Alfredo Calderón: "Es empequeñecer el mundo del pensamiento humano reducirlo a ideas claras" (La justicia, 16 de marzo de 1889). No cabe duda de que asistimos a un cambio en el planteamiento de qué deba ser lo literario, más alejado cada vez de una simple mimesis, a pesar de la cuestión palpitante, y que de la consideración de la excesiva potencia imaginadora como enfermedad, en los estudios de Jean Tissot, pasamos a su integración en el arte como un modo distinto y genuino de abordar la realidad. En este sentido el propio Clarín ofrece casos representativos, como el protagonista de La fantasía de un delegado de Hacienda, el cual llega a imaginar que acaba de morir de una pulmonía.

Lo expuesto hasta ahora me lleva a pensar que toda acción en el dominio del pensamiento lleva implícita su reacción, a veces igualmente legítima para el pensador mismo. Así Flaubert comentaba a Maupassant en una carta: “ ¿Ha creído alguna vez en la existencia de las cosas? No hay más verdad que la que hay en las relaciones, es decir, en la forma en que percibimos los objetos" (cit. Company-Ramón, 1986). De aquí al impresionismo no hay demasiados pasos.

Con todos los distingos planteables, aún el texto es lo bastante flexible como para destacar su conexión con el onirismo, en el sentido de un impulso creador, no de una resolución interpretativa o psicoanalítica. De este modo creo que lo ve también Laura de los Ríos, frente a las reservas manifiestas por Ramos-Gascón. Intentaré basar mis juicios en alguna reflexión. En Bergson leemos: "En el ensueño solemos ser indiferentes a la lógica, pero no incapaces de lógica. Diría, casi a riesgo de abordar la paradoja, que el efecto del que sueña es que razona demasiado. Evitaría el absurdo si asistiese como simple espectador al desfile de sus visiones. Pero cuando quiere a todo trance dar una explicación de ellas, su lógica, destinada a relacionar entre sí imágenes incoherentes, no hace sino parodiar la lógica de la razón y tocar en el absurdo" (1982, págs. 108-9). En el cuento hay una escena en la que el personaje-narrador, ya fundido a su cuerpo de difunto, dice soñar: "Soñé que uno de ellos — de los pies- era el Mississippí y el otro un río muy grande que hay en el norte de Asia y que yo no recordaba cómo se llamaba. ¡Qué tormento padecí por no recordar el nombre de aquel pie mío!" (pág. 170). Este soñar, sin embargo, no tiene despertar explícito alguno, aunque en el contexto es lo cierto que hubiera sido lo mismo utilizar otro verbo, del tipo pensé, o imaginé, o me pareció... Dado el grado de extrañeza alcanzado previamente no hay escalón alguno que nos señale el paso al sueño; la fluidez de las sensaciones visuales característica para Bergson de la literatura del ensueño, no cede hasta que el difunto es conducido al cementerio, y entonces se remansa sólo para crear mayor contras- 
te con las imágenes finales. Este contraste se agranda aún más porque cuando Ronzuelos, el protagonista, salta de la caja tras ser acusado por Roque Tuyo de tramposo y no ve a nadie, pensaríamos que todo lo anterior no fue más que una pesadilla y que es el momento de hacerse preguntas. Pero la "falta de tiempo disponible para detenerse , extrañarse, interrogarse, pensar" (Zambrano, 1986, pág. 27) vuelve a remitirnos a la atemporalidad de la psique mostrada en los sueños. Levantarse y no ver a nadie es como un despertarse sin salir del sueño, un acentuar la incertidumbre de si es o no real lo percibido.

La pasividad del personaje durante la mayor parte del cuento me hace pensar en una frase de Le Clézio a propósito de Les chants de Maldoror: "Celui qui dort subit l'anéantissement intermittent des facultés humaines" (1989, pág. 74) ${ }^{4}$, sólo que esta falta de conciencia que Maldoror vive como angustia es aprovechada como despiste por el autor para favorecer lo cómico.

Entramos en este punto a otro problema. ¿Cabe considerar Mi entierro como un cuento fantástico? Vaya por delante mi coincidencia con Harry Belevan en el no admitir lo fantástico como género, al menos no como género histórico. También estoy de acuerdo en considerar, como Barrenechea, que las nociones de Todorov extraño / fantástico / maravilloso, articuladas en torno a la resolución o no de la duda, son inservibles en muchos casos modernos, en los cuales el relato rechaza desde el principio que exista una verdad única y, por tanto no busca hallarla, crece espontáneamente sobre el eje de su ambigüedad o de su verdad ficticia. Elementos fantásticos como el desdoblamiento inicial, resuelto luego en una fusión repentina e inesperada, o la lectura de los pensamientos ajenos, no se insertan como contradicción de su contexto y lo fantástico así no llega a cuajar.

Está claro, en cualquier caso, que interpretaciones unívocas, ya desde la locura, ya desde lo fantástico, se excluyen mutuamente. Rechazada aquélla como una falsa pista dada por el autor, como primer lector que es, sobre su propio cuento, debo desestimar ésta basándome en el hecho de que los personajes no experimentan sorpresa ante la ruptura de lo verosímil, precisamente como quien, soñando, no se sorprende de poder volar. Aquí la literatura, como obra de la imaginación, "representa un universo del que se excluye la creencia (creencia en el sentido de certeza...)" (González, 1980, pág. 33). Alguien ha hablado, con mayor o menor fortuna, de lo neofantástico, que igual pudiera llamarse neomaravilloso, o también se ha propuesto el término insólito, si bien considero que en estos conceptos no se ha insistido sastante. El basculamiento que se produce en este tipo de relatos provoca que "evolucione como una nebulosa" (ibíd., pág. 85), sin pretender hacerse con una objetividad inalterable.

4. "El que duerme experimenta el anonadamiento intermitente de las facultades humanas". 
Señalo esta posibilidad de hacer una lectura desde una forma narrativa contemporánea sin tratar por ello de definir Mi entierro como un cuento insólito, al estilo de La Metamorfosis kafkiana. Ahora bien, aplicado a este relato el criterio de no-discusión, de asimilación con-natural de lo extraño en lo conocido, podemos caer en la apreciación errónea de que nos hemos trasladado al terreno de lo maravilloso. El problema suele ser casi siempre puramente terminológico. Probablemente, cuando G. Sobejano utilizó aquel concepto, daba a la palabra un sentido amplio, el que emplea Vax en su Arte y literatura fantástica, diferenciando luego lo feérico de lo fantástico. Lo maravilloso-feérico, sin embargo, responde a unas leyes, aunque ajenas a la realidad, específicas y que dan coherencia interna a todo el cuento. Frente a estas leyes para-reales, "lo insólito, más sutil y perverso, nos insinúa que la vida es una ficción" (ibíd., pág. 105); ya no es fruto del miedo a lo desconocido, como lo fantástico, sino de la progresiva alienación del hombre moderno. Poco importan algunas contradicciones cuando están siendo cuestionados aspectos que afectan tanto a lo espacio-temporal, como a lo teológico o a la propia identidad. Y si en el relato fantástico el personaje tenía una función activa, se rebelaba o trataba de defender su cosmovisión, en el neofantástico pasa a ser como un centro inmóvil cuya idea de la causalidad ha sido sustituida por un vacío lógico (ibíd., pág. 63). Estas condiciones sobre las que se construye lo insólito favorecen, además, la visión cómica, la cual era improcedente en el relato fantástico tradicional. Esto es lo que sucede en Mi entierro, donde el extrañamiento viene a superponerse a las leyes del disentimiento y de la tolerancia del chiste.

La locura del personaje no es en sí sino una licencia para dejar libre la fantasía cómica, "razonable a su modo, hasta en los mayores extravíos" (Bergson, 1983, pág. 12). De aquel José Ido comentaba Clarín: “Dónde habrá cosa más graciosa que su borrachera carnal?" (Una carta y muchas digresiones, 1987, pág. 112), él que tanta facilidad demostró para el humor. Y Mi entierro es un buen ejemplo de esa "innata tendencia a establecer las asociaciones más incongruentes" de que habla Gramberg (1958, pág. 197). Este crítico define, asimismo, una de las características del humor como "la capacidad de ver y sentir yuxtapuestas y al mismo tiempo cosas del orden ideal y real que aisladamente no provocarían humorismo alguno (ibíd., pág. 78), yuxtaposición que este cuento refleja bien en el lenguaje: "exclamé enroco y seguí adelante" (pág. 167); o luego: "-Chico, le dije cuando le tuve a salto de peón, ${ }_{i} \mathrm{Ni}$ que fuera un caballo; vaya modo de comer que tienes!" (pág. 168). Del mismo modo podemos encontrar todos los criterios tradicionales que delimitan lo cómico: contradicción, desacralización, sorpresa, complicidad, juego, lógica y absurdo.

Pero este cuento entra de lleno en el tema de la muerte. ¿Cabría calificarlo de macabro? Martin Grotjahn, en su Psicología del humorismo aborda justamente la relación entre el humor y la muerte. La irreverencia, la trasgresión del 
tabú, son básicas en muchos momentos cómicos. Todo depende, sin embargo, de nuestro grado de tolerancia, es decir, de que seamos capaces de separar esa trasgresión y nuestras creencias. Así, Wenceslao Fernández Flórez contaba que "hay una circunstancia ante la cual el humorismo no puede: ante la muerte". Por su parte, comenta Antonio Espina: "Las ceremonias fúnebres suelen producir en el espectador desinteresado, o sea, ajeno en su intimidad al hecho luctuoso, reacciones de humorismo a propósito de cualquier detalle, de cualquier situación que desentone con el negativismo fundamental de lo fúnebre, de lo macabro" (1965, págs. 82-3). Estas reflexiones nos hacen pensar, sin duda, en la santa cachaza de don Angel Cuervo en su trato con los moribundos.

En Mi entierro la omnisciencia crea el desengaño, que a su vez acentúa el escepticismo necesario para levantar sobre él el humor. De esta manera, la narración en primera persona se convierte en exponente del vivir relativizado. El humorista se saldrá de sí mismo para ser en todo, para ver el derecho y el revés al mismo tiempo, y enfrentar la realidad admitida con otra realidad supuesta, superponiendo lo que nadie ve en lo que todos ven.

"No hay mayor enemigo de la risa que la emoción", dirá Bergson. No obstante, otra era la idea de lo cómico en autores anteriores. Para Taine o Tackeray, el humorista debía, en último término, despertar nuestra compasión por lo mismo que censura. De esta misma opinión era Palacio Valdés cuando afirmaba que "no fue Alas un humorista en el sentido verdadero de la palabra. Para ello le faltaba la piedad" (1941, pág. 96).

También Cejador y Frauca expondrá su opinión al respecto, más próxima a la expresada por Gómez de la Serna en Automoribundia, lo mismo que Manuel de la Revilla. Esta nueva concepción del humorismo nace más de la pura subjetividad, de una ironía filosófica, y tiene como finalidad en sí el hecho catártico del instante cómico. De una a otra encuentro el paso que va de lo social a lo individual: la risa como vía de lo didáctico, un bien para la comunidad, frente a la risa como un guiño particular entre sujetos que asisten a un mismo espectáculo, a una misma realidad castrante.

Ciñéndonos al relato podemos comprobar que participa de las visiones que acabo de exponer sobre lo cómico, si bien, al tratarse de un relato en primera persona, donde el objeto de burla es muchas veces el propio narrador ficcionalizado, pensamos más en el escéptico que se ríe de sí mismo. No sucede esto cuando la focalización es centralizada por un personaje, como ocurre en el discurso de D. Mateo, o antes, en el monólogo interior de la mala esposa (cuya técnica de entrecruzamiento de discursos distintos vemos también en Un niño maligno, cuento de A. Chéjov). De estas situaciones fácilmente podríamos extraer el juicio de Tackerey en lo referente al "desprecio por la mentira y la hipocresía” (vid. Martínez-Collado, 1988, pág. 222). Con todo, vence en el 
texto la imagen simbólica del ajedrez y el leit motif absurdo de la humedad, que nos hablan más acerca de la vida como juego pasivo.

Volviendo nuevamente al tema de la locura desde esta perspectiva, pienso que, como dice A. Espina, "la locura pone una barrera infranqueable al humor, en cuanto obnubila la conciencia. Pero es y fue una de sus fuentes, para el cuerdo [...] la incoherencia, las extravagancias del loco" (1965, pág. 85). Pero es que, además, la del humorista "viene a ser una posición arriesgada, próxima a la locura" (Vilas, 1968, pág. 60). En el texto se unifican las voces del personaje, que es el doble loco del narrador, éste, que en virtud de una licencia se autoconcede la omnisciencia, y el autor-humorista, que es quien dispone el tono y el ritmo. A estos dos elementos narrativos dedica Jean Sareil un espacio en L'écriture comique, resumiendo cómo el ritmo es el elemento más importante de la narración cómica, en cuanto que da al cuento calidad de tal, mientras que en el drama o la novela seria este papel corresponde, por lo general, a la historia (vid. Sareil, 1984, pág. 151). En cuanto al tono juzga que su papel es precisamente el de crear un ambiente en el que la desmesura parecerá la forma más habitual de hacer o de pensar (ibíd., pág. 175).

En el cuento de Clarín la primera ruptura con el plano de lo sensato crea ya un tono que justifica las restantes, hasta el cierre final, desconcertante y cargado de todas las significaciones anteriores, multiexpresivo. Conocemos la lógica del personaje, por eso nos hace gracia que compadeciendo al difunto, al cual aún no conoce, exclame: “Alguna víctima de la humedad!” (pág. 168), exclamación que inmediatamente aprovecha el artista para intercalar la voz del sereno: "dicen si ha muerto de una borrachera", sirviéndose de la mínima ambigüedad precedente. Luego, la alienación del personaje, su indiferencia ante lo que resulta ser su propio cadáver - lo cual, tratado de este modo, nunca he visto en autores anteriores-, ridiculizado incluso por el narrador, la vacilación hacia lo trágico subjetivo cuando lo más terrible parece ser no recordar el nombre de su pie-río, todo ello contribuye a que los registros tonales, realista y fantástico, satírico y grotesco, se armonicen, tras la desconcertante imagen última. Paralelamente el ritmo, rápido cuando el narrador es protagonista, más demorado cuando se practica la omnisciencia selectiva, contribuye a destacar sobre el conjunto la tensión final.

Réstame entrar en lo que de grotesco han señalado Ramos-Gascón y, sobre todo, Laura de los Ríos. En la revisión del concepto nos encontramos por un lado con la idea romántica, que subrayaba "la yuxtaposición de lo feo y hermoso, combinando lo cómico y lo trágico en orden a despertar la compasión del lector" (Ziomek, 1983, pág. 11). Así Justus Moser, Campbell, Lee Byron Jenning, Víctor Hugo..., unos destacando más los elementos repugnantes, otros los cómicos. Por otro lado, la idea de lo grotesco en el siglo XX: "No solamente 
se designa así a lo que es deforme o fantástico, sino también a todos aquellos actos o expresiones que ponen de manifiesto los aspectos sórdidos y repulsivos de la vida" (ibíd., págs. 11-12). Ziomek concreta que lo grotesco tiene un triple efecto: provocar el horror, la risa y el asombro: "Para llegar a lo grotesco - continúa - hay que añadir al humor, la sátira y la exageración que constituyen la caricatura, un elemento nuevo: la extrañeza" (1983, pág. 14). Este factor coincide con lo que Wolfang Kayser denomina distanciamiento, el cual puede ser más o menos cómico o siniestro, considerado también su juego con lo absurdo (vid. Martínez, 1984, pág. 33). La extrañeza, por lo general, en la literatura anterior al siglo $\mathrm{XX}$, era expresada por medio de personajes $\mathrm{y}$ espacios, ridículos o deformes, muchas veces simbólicos, los cuales eran tratados de modo que el lector sintiera rechazo, destruyendo así toda posibilidad de identificación.

Visto esto, personalmente no sabría decir si Mi entierro es más satírico que fantástico o viceversa. En este relato no encontramos exactamente personajes grotescos, aunque sí situaciones grotescas, las cuales son presentadas por el autor ya de modo cómico — sin intencionalidad crítica-, ya de modo satírico. La escena que más claramente podemos considerar grotesca comienza con la visión del cadáver: "Estaba en camisa, sin calzoncillos, pero con calcetines" (pág. 169). Y más adelante, a propósito de provocar el contraste con la solemnidad con la sacralidad de lo funerario, se nos cuenta: "Una de las hachas de cera se torció y empezaron a caer gotas de ardiente líquido en mis narices" (pág. 170), aumentando este contraste la descripción del gato, familiarmente enroscado junto al difunto, y un moscón sobre las narices de éste, cubiertas de cera. Posteriormente la impresión de lo grotesco desaparece bajo el humor o la sátira, reapareciendo en alguna pincelada como ese defenderse del personaje, ya en el cementerio, fémur en ristre. Por el contrario, la ironía va en aumento, apoyada en la inautenticidad que late bajo las relaciones y la conducta de los hombres. Por eso el personaje llega a decir: "Mi mujer, Perico, Clemente, el partido, don Mateo... y sobre todo Roque Tuyo, me dan asco" (pág. 176). Digamos que la situación, es decir, el comportamiento de la sociedad aquí representada, es demasiado reconocible como para ser grotesca y, de acuerdo con H. Martínez, creo que "la presencia de elementos grotescos no necesariamente justifica clasificar una obra como grotesca" (1984, pág. 31) 5 .

Otra cuestión sería considerar lo grotesco como un modo de explorar preocupaciones metafísicas o existenciales. Como una forma de dar salida al desengaño barroco era un juego de paradojas que envolvía al hombre en desacuerdo con su entorno, pero con la esperanza clara en una idea superior. En

5. Para este crítico, "el grotesco, aunque carezca de verosimilitud, provoca numerosas sensaciones contradictorias: sonrisa, repugnancia, sorpresa, congoja ante un mundo que está desquiciado mientras ya no encontramos apoyo alguno". (1984, pág. 25) 
el siglo diecinueve la crisis filosófico-religiosa se reflejará en la literatura haciendo que ésta se centre, progresivamente, en todo tipo de alienaciones. En este sentido, el humor, creo, sirve de alivio a la conciencia de dicha alienación.

Teniendo en consideración el momento en que pudo ser redactado Mi entierro, posiblemente tras la frustración de no ver publicados los artículos sobre el problema agrario andaluz que tantos ires y venires le debieron costar a él y a su mujer, recién casados, o tal vez por el alejamiento en que se hallaban a causa de tener nombrada la cátedra en Zaragoza, ello es que la capacidad irónica y crítica del escritor pudo haberse agudizado. No cabe objetar que tras determinados personajes el autor está tipificando, y censurando, ciertos caracteres humanos. La huella de lo moral está impresa desde la mujer adúltera hasta el inepto orador, pasando por el falso amigo y el desengaño político. La ética en la estética, como profundamente muestra Lissorgues (vid., 1980 y pról. 1989). Mi intención, no obstante, ha sido la de evidenciar la riqueza de voces que configuran este relato del genial Clarín, así como la de complicar la visión que hasta poco ha se tenía del artista, el cual, como decía Baudelaire, "no es artista más que a condición de ser dual y de no ignorar ningún fenómeno de su doble naturaleza" (1988, pág. 51). Juzgue el lector sobre la necesidad de establecer criterios para una posible clasificación de Mi entierro sin que se anule alguno de los componentes significativos que posee.

\section{BIBLIOGRAFÍA}

ALAS, Leopoldo. 1971. Solos de Clarín, Madrid, Alianza.

—. 1984. Pipá, ed. RAMOS-GASCON, Madrid, Cátedra.

-. 1985. Juan Ruiz, ed. Martín GAMERO, Madrid, Espasa-Calpe (col. Austral).

-. 1987. Mezclilla, Barcelona, Lumen.

BAUDELAIRE, Charles. 1988. Lo cómico y la caricatura, Madrid, Visor.

BERGSON, Henri. 1982. La energía espiritual, Madrid, Espasa-Calpe (col. Austral).

-. 1983. La risa, Barcelona, Orbis.

BONET MOJICA, Laureano. 1984. Clarín, Jean Paul, Baudelaire: Un tríptico simbolista. En Clarín y La Regenta en su tiempo, Oviedo, Universidad.

CLEZIO, Jean-Marie Le. 1987. Le rêve de Maldoror. En Sur Lautréamont, París, Complexe.

COMPANY-RAMÓN, José María. 1986. La realidad como sospecha, Valencia, Minneapolis.

DUPLESSIS, Yvonne. 1972. El Surrealismo, Vilassar de Mar (Barcelona), col. ¿Qué sé?

EBERENZ, Rolf. 1989. Semiótica y morfología textual del cuento naturalista, Madrid, Gredos. 
ESPINA, Antonio. 1965. El genio cómico y otros ensayos, Madrid-Santiago de Chile, Cruz y Raya (Cruz del Sur).

FINNÉ, Jacques. 1980. La littérature fantastique. Essai sur l' organisation du surnaturel, Bruxelles, Université.

GONZÁLEZ, Ana. 1980. Continuidad de lo fantástico, Barcelona, Punto.

GRAMBERG, Ernest. 1958. Fondo y forma del humorismo en Leopoldo Alas "Clarin", Oviedo, Instituto de Estudios Asturianos.

LISSORGUES, Yvan. 1989a. Clarín político, Barcelona, Lumen, v.I

-. 1989b. pról. a ALAS, Leopoldo, Narraciones breves, Barcelona, Anthropos.

LUGONES, Leopoldo. 1982. La última carambola, en Cuentos desconocidos, ed. BARCIA, Buenos Aires, Eds. del 80.

MARTÍNEZ, Herminio. 1984. El arte grotesco en las tragedias grotescas de Arniches y Valle-Inclán, New York, NYUniversity.

MARTÍNEZ-COLLADO, Antonio. 1988. Una teoría personal del arte: Ramón Gómez de la Serna, Madrid, Tecnos.

MAUPASSANT, Guy de. 1976. El horla, Barcelona, Argonauta.

PALACIO VALDÉS, Armando. 1941. Epistolario a Clarín, Madrid, Escorial.

RAMOS-GASCÓN, Antonio. 1984. Introd. a ALAS, Leopoldo, Pipá, Madrid, Cátedra.

RICHMOND, Carolyne. 1983. Introd. a ALAS, Leopoldo, Treinta relatos, Madrid, Espasa-Calpe (col. Austral).

RÍOS, Laura de los. 1965 Los cuentos de Clarín. Proyección de una vida, Madrid, Revista de Occidente.

SAREIL, Jean. 1984. L'écriture comique, París, PUF.

SOBEJANO, Gonzalo. 1985. Clarín en su obra ejemplar, Madrid, Castalia.

TODOROV, Tzvetan. 1970. Introduction à la littérature fantastique, París, Seuil.

VAX, Louis. 1981. Las obras maestras de la literatura fantástica, Madrid, Taurus.

VILAS, Santiago. 1968. El humor y la novela española contemporánea, Madrid, Guadarrama.

ZAMBRANO, María. 1986. El sueño creador, Madrid, Turner.

ZIOMEK, Harry. 1983. Lo grotesco en la literatura española del Siglo de Oro, Madrid, Alcalá. 